\title{
PARAMETRIC STUDY OF RESPONSE SPECTRUM OF RAMMED EARTH CONSTRUCTION IN MOROCCO
}

\author{
J. Balil \\ Laboratory Engineering Energy, Materials and Systems (LGEMS) \\ National School of Applied Sciences, University Ibn Zohr, Agadir, Morocco.

\section{A. Atmani} \\ Laboratory Engineering Energy, Materials and Systems (LGEMS), \\ National School of Applied Sciences, University Ibn Zohr, Agadir, Morocco.

\section{Agliz} \\ Laboratory Engineering Energy, Materials and Systems (LGEMS), \\ National School of Applied Sciences, University Ibn Zohr, Agadir, Morocco.
}

\begin{abstract}
Today, in the construction field, rammed earth structures have environmental, socio-economic and technical advantages, but they must be regulatory and fulfil the standards. The aim of this study is evaluation the seismic response of rammed earth structures. Indeed, this work includes a determination of the response spectrum through accelerations and experimental displacements with an spectral evaluation in form of the envelope spectrum. A determination of the damping coefficient of the structural response based on a standardized spectral parametric study to be incorporated in the new seismic earth construction regulation RPCT and the seismic regulation RPS 2011 to set up a framework for the seismic study of structures in rammed earth in Morocco. Copyright (C) 2010 Praise Worthy Prize S.r.l. - All rights reserved.
\end{abstract}

Keywords: Rammed Earth, Seismic, Dumping's Coefficient, RPS 2011, Spectrum Response

Cite this Article: J. Balil, A. Atmani and D. Agliz, Parametric Study of Response Spectrum of Rammed Earth Construction in Morocco, International Journal of Civil Engineering and Technology, 11(7), 2020, pp. 21-28. https://iaeme.com/Home/issue/IJCIET?Volume $=11 \&$ Issue $=7$

\section{INTRODUCTION}

Buildings built of rammed earth, present today a significant renewal in terms of sustainable development, ecology, comfort and socio-economic aspects, given the advantage of rammed earth to be a material used without negative effects on the environment. Rammed earth is 
prepared using raw materials extracted in the vicinity of the project. Thus, rammed earth significantly reduces the costs of energy from extraction, transportation, and manufacturing.

Inspired by linear spectral calculation for reinforced concrete given by RPS [1], we set the response spectrum dedicated to rammed earth structures. This method consists in using a procedure of direct dimensioning by the method of shear forces at the base of a structure [2]. Indeed, we identify firstly by this method the seismic effort that can be applied, and then proceed to a verification of the movements of the structure.

The main objective of this work concerns the definition of the response spectrum for buildings built of rammed earth following RPS 2011. The first phase of this study defines the response spectrum by exploiting an earlier study conducted on the seismic behavior of a rammed earth building [3]. The second phase will be dedicated to the rammed earth building modeling of the previous study [3] with the response spectrum concluded. The results show a correlation between calculated displacements and experimental displacements.

\section{ANALYTICAL STUDY}

\subsection{Seismic Formulation}

Seismic excitation causes displacement of the structure of a building. Indeed, for a structure, the displacement of each point depends on the rigidities of the elements that constitute it and the distribution of the masses in the structure. The implementation of the response spectrum is based on a model represented by an equivalent mass oscillator " $\mathrm{M}$ ", a viscous damping coefficient " C " and stiffness " K" (Figure 1). When this model is submitted to the base of an earthquake in the form of an "ag (t)" acceleration, the equation of motion is given by the fundamental principle of dynamics [4]:

$$
M \ddot{U}(\mathrm{t})+\mathrm{CU}(\mathrm{t})+\mathrm{KU}(\mathrm{t})=-\mathrm{Ma}_{\mathrm{g}}(\mathrm{t})
$$

Where $\ddot{U}(t), \dot{U}(t)$ and $U(t)$ are respectively the acceleration, the speed and the displacement of the studied model at time $t$.

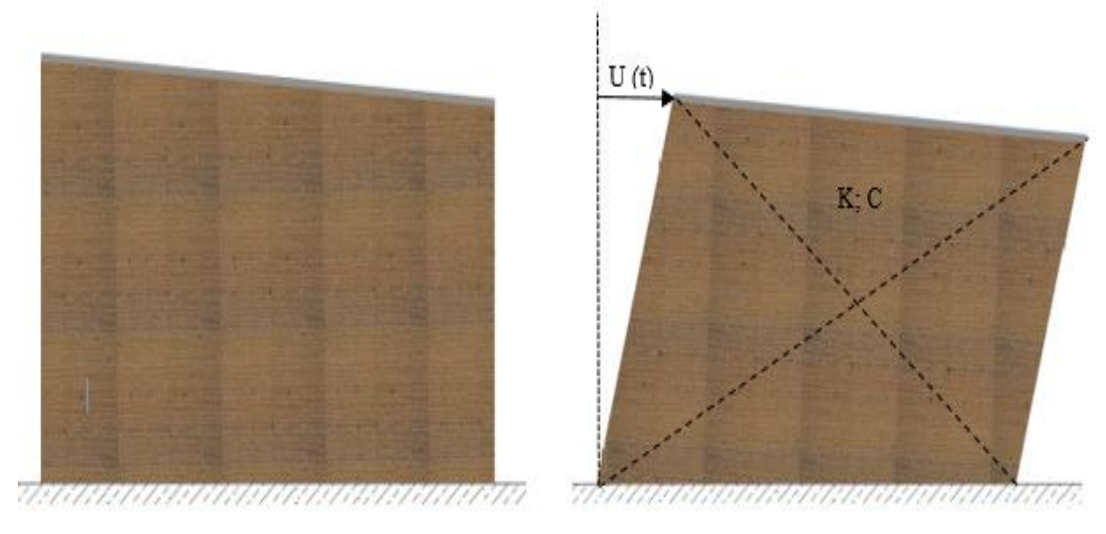

Figure 1 Front view of the model studies in rammed earth (static case on the left and case solicited on the right)

Thereafter, the maximum amplitude of the model response is determined for each applied acceleration. The results are plotted in a graph according to the period T [5] (Figure 2). 


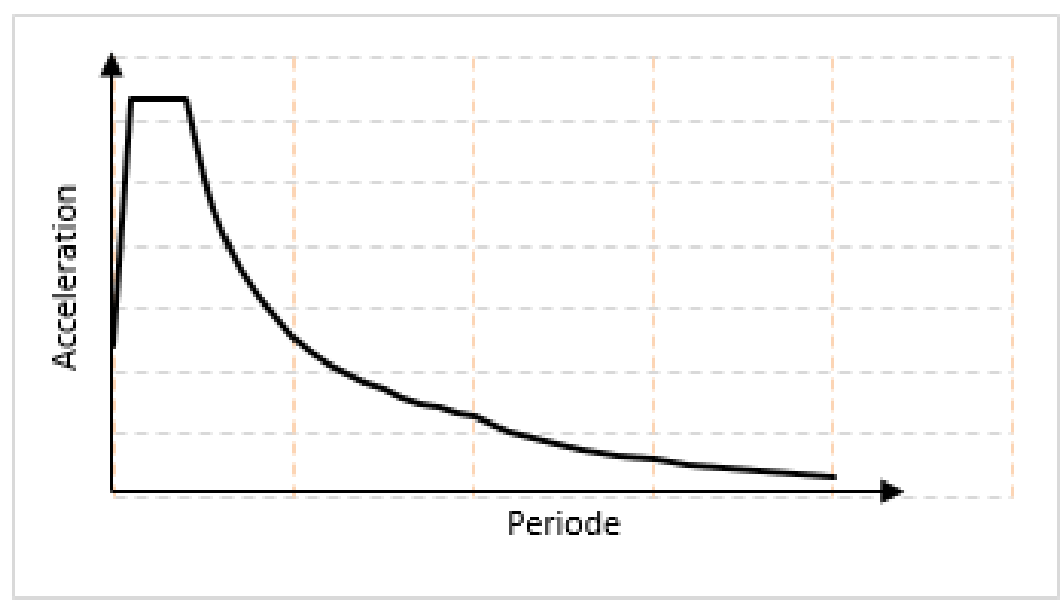

Figure 2 General Horizontal Response Spectrum [5]

The seismic demand is defined in the form of a (pseudo) elastic acceleration spectrum Sae, in which the spectral accelerations are given as a function of the natural period of the structure T. The specified damping coefficient is taken into account in the spectrum [6].

\subsection{Rammed Earth}

Rammed earth is a building material made from raw earth extracted on site or near the project.

Clay acts as a binder that gives the mud cohesion to have the resistance it needs to support the loads thereafter. To make rammed earth walls, the soil is compacted between forms called wooden or steel benches. The compaction is implemented in successive layers of $20 \mathrm{~cm}$ by means of a traditional or pneumatic lady. After compaction, the thickness of each vertical layer is around $15 \mathrm{~cm}$. Such as the thickness of the rammed earth walls is about $40 \mathrm{~cm} \mathrm{[7].}$

The mechanical properties of rammed earth are very varied. They depend mainly on the nature of the materials and their implementation.

Several technical studies were made for the evaluation of the mechanical properties of rammed earth, the results obtained show that the compressive strength fc of rammed earth is of the order of 3.4 to $4.0 \mathrm{MPa}$ [8]. For the tensile strengths $\mathrm{ft}$ is given according to the compressive strength $(\mathrm{ft}=0,11 \times \mathrm{fc})[9]$.

A summary of the properties of the earth material is presented in Table 1.

Table 1 Mechanical characteristics of Rammed earth [10]

\begin{tabular}{cc}
\hline $\begin{array}{c}\text { Compressive strength (MPa) } \\
\text { MAN08 }\end{array}$ & Young's module (MPa) \\
\hline 2,46 & 160 \\
\hline
\end{tabular}

To meet the need both to preserve this mode of construction and to regulate it, Morocco has adopted the RPCT standard [7], which provides designs and building regulations to be followed according to the seismic zones. However, there is a need for the evaluation of the spectrum of response as the case for concrete standards of concrete [1].

\section{PARAMETRIC STUDY}

\subsection{Model - Conception}

The studied model is a one-level rammed earth structure. Two walls main face $(\mathrm{P})$ and rear face (A) of $2.80 \mathrm{~m}$ and two other side walls $(\mathrm{G}$ and $\mathrm{D})$ of $3.20 \mathrm{~m}$. 
The thickness of the four walls is $25 \mathrm{~cm}$, the heights of the façade walls $(\mathrm{P})$ and facade (A) are respectively $2.55 \mathrm{~m}$ and $2.28 \mathrm{~m}$ (Figure 3); their importantes rigidities in plan make it possible to control the displacement of the model following the two seismic zones of acceleration $0.284 \mathrm{~m} / \mathrm{s}^{2}$ and $0.741 \mathrm{~m} / \mathrm{s}^{2}$ [1]. The model is designed according to the Moroccan seismic code RPS [1].

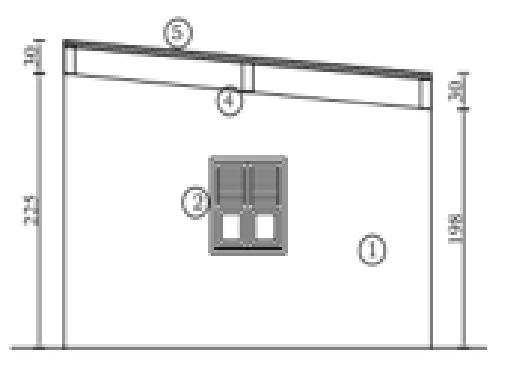

(a) Elevation view- Face G

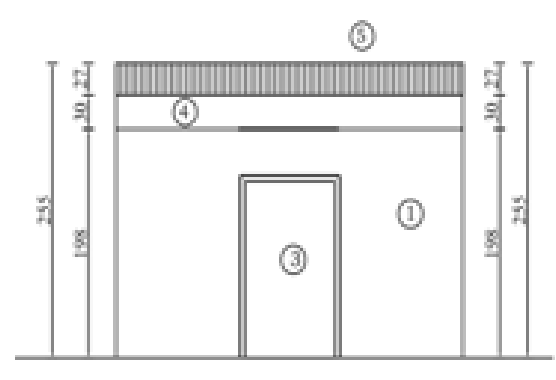

(b) Elevation view - Face P

Figure 3 Conception of the study model

\subsection{Spectrum of Response (Rammed Earth Structure)}

Taking into account the accelerations and measured displacements of the studied model [3], we determined firstly the Ti periods of several vertical points of the building, following the relationship 2 [11]:

$$
T_{i}=2 \pi \sqrt{\frac{D_{i}}{A_{i}}}
$$

Then we determined for these points the dynamic amplifications $\Delta \mathrm{i}$ through the formula 3 :

$$
\Delta_{i}=\frac{A_{i}}{A_{0}}
$$

The determination of the dynamic amplification and the periods allowed us to draw the curves of the amplifications- period $\mathrm{T}$ for each phase.

So, thanks to these curves, the dynamic amplification envelope curve can be drawn by aligning with the RPS regulation [1].

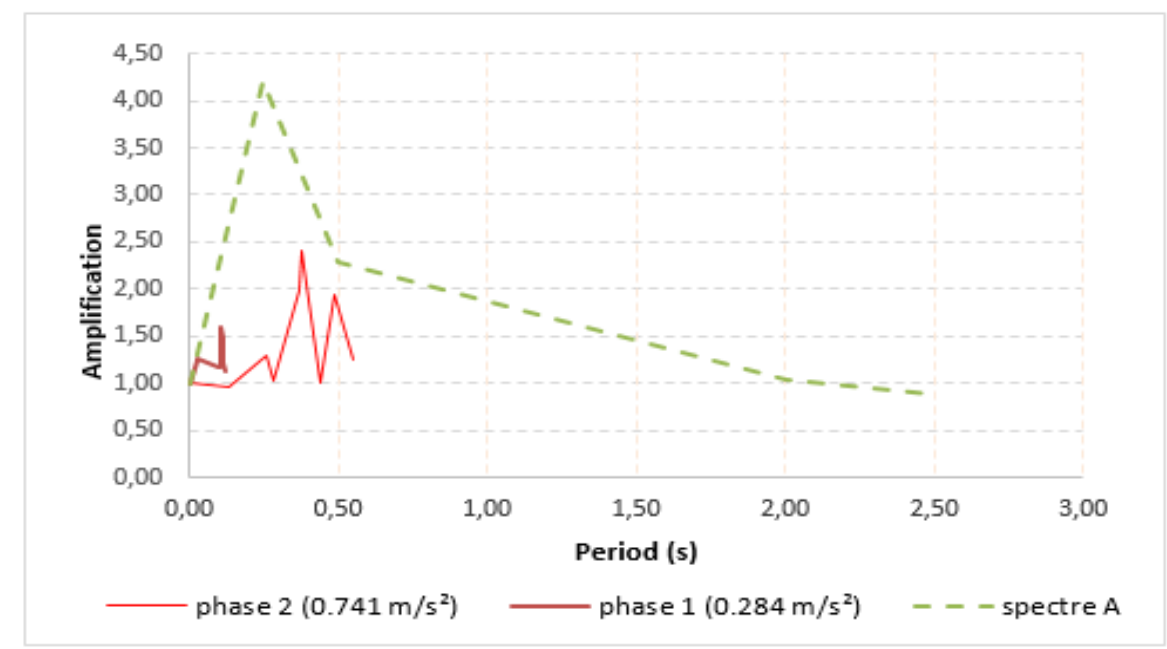

Figure 4 Specter envelope evaluated 
With this envelope curve (Figure 4), we have determined the dynamic amplification curves according to the RPS regulation [1] while having corrected the curves represented in Figure 5. This allows us to finally determine the damping coefficient for rammed earth structures.

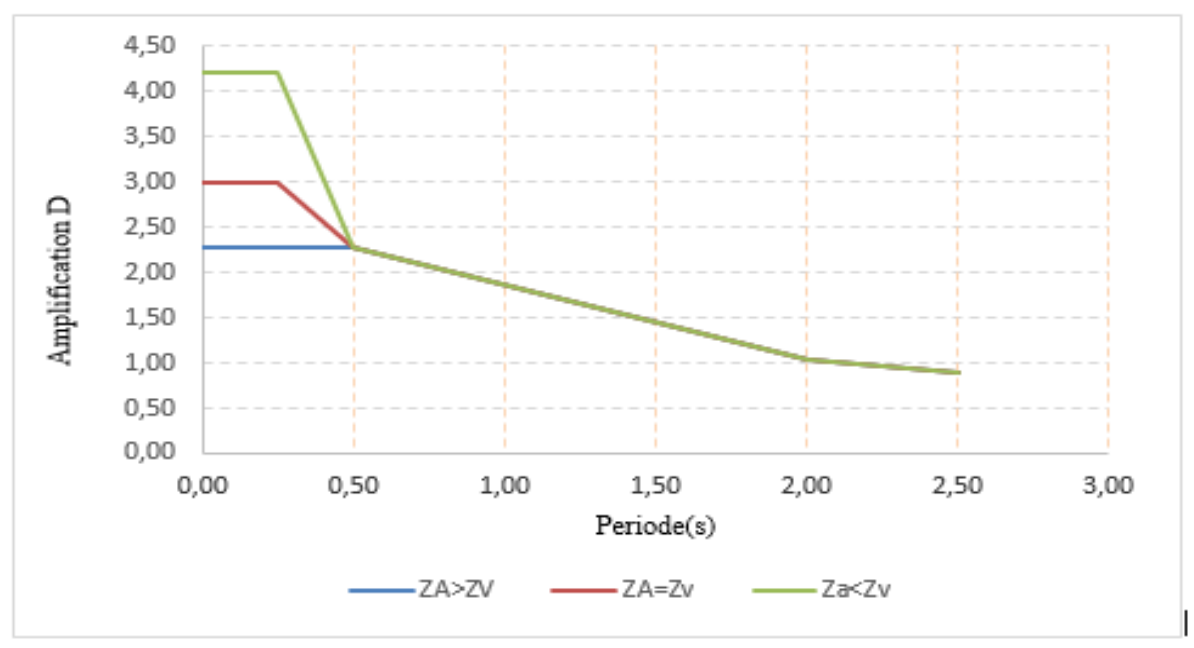

Figure 5 Spectrum of response

The analytical projection of spectral data developed, allowed us to establish three formulas according to the areas of acceleration and the areas of speed on the basis of the ratio $\mathrm{Za} / \mathrm{Zv}$ (Table 2):

Table 2 Dynamic amplification proposed for rammed earth

\begin{tabular}{cccc}
\hline Ratio the areas $\mathbf{Z a} / \mathbf{Z v}$ & \multicolumn{3}{c}{ Period $\mathbf{~}$} \\
\hline $\mathrm{Za} / \mathrm{Zv}$ & $\leq 0.25$ & $0.25<\mathrm{T}<0.50$ & $0.50 \leq$ \\
\hline $1<$ & 2,28 & 2,28 \\
1 & 3 & $-2.88 \mathrm{~T}+3.72$ & $1,436 / \mathrm{T}(2 / 3)$ \\
$1>$ & 4,2 & $-7,68 \mathrm{~T}+6,12$ & \\
\hline
\end{tabular}

The value of the dynamic amplification calculated from a correction of the spectra obtained in this work increases according to the reduction of the ratio of $\mathrm{Za} / \mathrm{Zv}$.

A simplified comparison between these amplification values found for the rammed earth material and those corresponding to the concrete mentioned in [1], shows a weak amplification for the concrete [12] than for the rammed earth; this can be attributed to the difference in depreciation value between the two materials.

\subsection{Assessment of Damping Coefficient}

The procedure used to determine rammed earth damping is based on a representation of the response spectrum. The representation of this spectrum obtained requires a correction of the normalized spectrum [1] by multiplying the ordinates of the spectrum of Figure 5 by the coefficient $\mathrm{m}=(5 / \xi) 0.4$ [13] where $\xi$ is the damping of the rammed earth

The initial damping of the normalized SPR spectrum [1] is five percent (5\%) of critical damping. The model has three different elasticity limits and three different periods. For each period, the spectral acceleration was determined from the response spectrum [14].

To do this, we applied a correction to the normalized spectrum, as suggested by [1]. Multiplying the ordinates of the spectrum by the coefficient: $m=4.21 / 3.5=1.20$

Therefore the damping coefficient of rammed earth is: $\xi=3,17$. 


\subsection{Comparative Approach}

The prototype object of the experimental study was modeled using the finite element method [15] and adapted to civil engineering structures [16] (Figure 6). Subsequently, the seismic calculation was performed by introducing the damping coefficient obtained in this study.

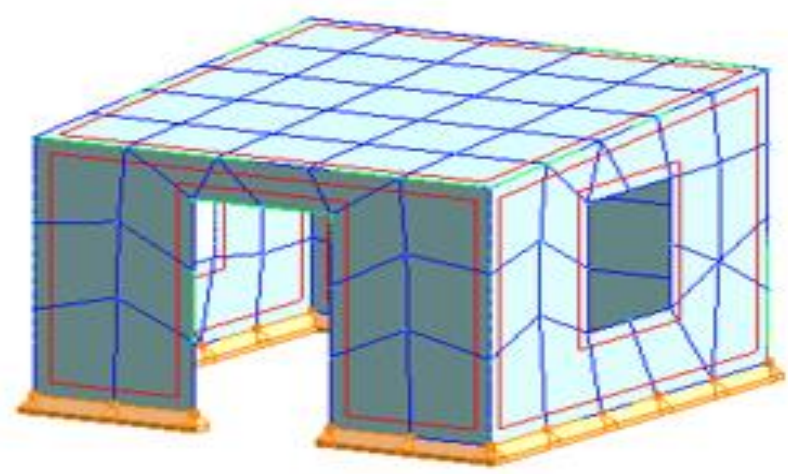

Figure 6 Meshing of the studied building

For the purpose of evaluating the structural response using the proposed response spectrum of rammed earth, under different seismic excitations, with integration of the response spectrum of figure 5 makes it possible to determine the displacements of the studied model (including an overall load of the roof of $220 \mathrm{~kg} / \mathrm{m}^{2}$ ) (Table 3 ) :

Table 3 Displacement value - calculated experimental [3]

\begin{tabular}{cccc}
\hline $\begin{array}{c}\text { Requested } \\
\text { acceleration }\end{array}$ & $\begin{array}{c}\text { Calculated } \\
\text { displacement }(\mathbf{m m})\end{array}$ & $\begin{array}{c}\text { Reference } \\
\text { displacement } \\
[\mathbf{3}] \mathbf{( m m})\end{array}$ & $\begin{array}{c}\text { Gap } \\
\mathbf{\%}\end{array}$ \\
\hline 0,284 & 1,142 & 1,140 & 0,170 \\
0,741 & 2,978 & 3,300 & 9,500 \\
\hline
\end{tabular}

Figure 7 graphically shows displacements at different points in the model with acceleration $\mathrm{A}_{0}=0.284 \mathrm{~m} / \mathrm{s}^{2}$.

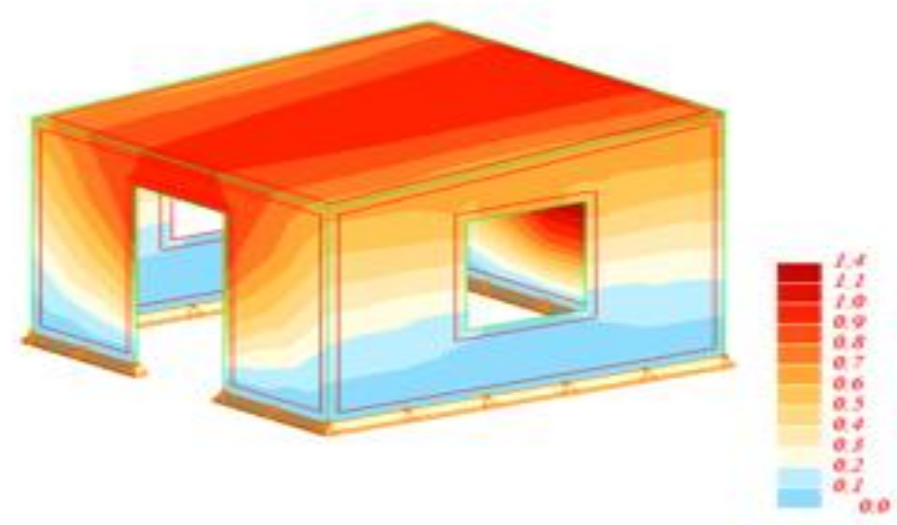

Figure 7 Seismic displacements - $\mathrm{A}_{0}=0,284 \mathrm{~m} / \mathrm{s}^{2}$

The evaluation of the displacements calculated for the two models of prototype and [3] show a concordance for the acceleration of $0.284 \mathrm{~m} / \mathrm{s}^{2}(0.17 \%$ difference $)$, which means that the calculated value of the damping 3.17 is validated. For the acceleration of $0.741 \mathrm{~m} / \mathrm{s}^{2}$ there 
is a difference of $9.50 \%$ which can be justified by the appearance of the elastoplastic phase in the sense that the depreciation is no longer constant in this case.

Taking into account the accelerations and measured displacements of the studied model is a one-level rammed earth structure. Two walls main face $(\mathrm{P})$ and rear face $(\mathrm{A})$ of $2.80 \mathrm{~m}$ and two other side walls (G and D) of $3.20 \mathrm{~m}$.

The thickness of the four walls is $25 \mathrm{~cm}$, the heights of the façade walls (P) and facade (A) are respectively $2.55 \mathrm{~m}$ and $2.28 \mathrm{~m}$ (Figure 3); their important rigidities in plan make it possible to control the displacement of the model following the two seismic zones of acceleration $0.284 \mathrm{~m} / \mathrm{s}^{2}$ and $0.741 \mathrm{~m} / \mathrm{s}^{2}$ [1]. The model is designed according to the Moroccan seismic code RPS [1].

\section{CONCLUSION}

The work carried out in this study presents a linear spectral analysis method for the design and verification of rammed earth structures under seismic loading. It is based on the acceleration-period diagram which allowed us to verify the structural stability by the displacement method. This method allowed us to propose an improvement of the seismic regulation [1] and also RPCT [7] by integrating the proposed methods of calculation for the rammed earth structures, through an evaluation of the response spectrum and a definition of damping coefficient for this type of structures with an approximate value set at 3.17.

The comparison of the results obtained with experimental results shows a concordance of the values.

\section{REFERENCES}

[1] RPS 2011, Règlement ParaSismique Ministère de l'habitat et l'aménagement de l'espace, Maroc,

[2] N. Djebbar, Contribution à l'Etude de la Performance Parasismique des Eléments Linéaires en Béton, Ph.D. dissertation, Université de constantine, Algérie, 2006.

[3] B.Saavedra, J.Marcial, T.Ruíz, S.Nicola, V.Vargas, and J.Martín, Refuerzo de Construcciones de Adobe con Elementos Producidos Industrialmente: Ensayos de Simulación Sísmica. DAI-3088, 2006

[4] B. D'Andréa-Novel, M.C. Lara, Commande linéaire des systèmes dynamiques, (Presses des MINES, 2000).

[5] Eurocode 8 (EC8), European Committee for Standardization, British Standards Institution and Standards Policy and Strategy Committee 2005, design of structures for earthquake resistance.

[6] P.Fajfar, A Nonlinear Analysis Method for Performance-Based Seismic Design. Earthquake Spectra, 16(3) pp.573-59, (Aug. 2000).

[7] RPCT, Reglement Parasismique pour les Constructions en Terre, Comite national des constructions en terre, Maroc, 2013.

[8] L. Miccoli, U. Müller, and P. Fontana, Mechanical behaviour of earthen materials: A comparison between earth block masonry, rammed earth and cob, Construction and Building Materials. 61, pp.327-339, (Jun. 2014).

[9] T.Bui, A. Limam, and S. Maximilien, 2014. Failure of rammed earth walls: From observations to quantifications, Construction and Building Materials. 51, pp.295-302, (Jan. 2014).

[10] V. Maniatidis, and P.Walker, Structural Capacity of Rammed Earth in Compression, Journal of Materials in Civil Engineering. 20(3), pp.230-238,(Mar. 2008) 
Parametric Study of Response Spectrum of Rammed Earth Construction in Morocco

[11] V. Davidovici, Conception et construction parasismique, (Edition Afnor et Groupe Eyrolles, 2016).

[12] BAEL 91 modifies 99, règles techniques de conception et de calcul des ouvrages et constructions en béton armé suivant la méthode des états limites (Éd Eyrolles, 2000).

[13] AFNOR. Règles PS applicables aux bâtiments, dites Règles PS92.NF P 06-013 / DTU Règles PS92; 1995.

[14] FEMA 440, Improvement of nonlinear static seismic analysis procedures, Applied Technology Council (ATC55 Project) and Federal Emergency Management Agency, (2004).

[15] G. Dhatt, and G. Touzot, Une présentation de la méthode des éléments finis, (Presses Université Laval, 1981)

[16] RSA, Robot Structural Analysis, Computer and structures, tutorial - sismic simulation analysis. 